\title{
Fish larvae, growth and biomass relationships in an Australian arid zone river: links between floodplains and waterholes
}

5 Balcombe, S.R., Bunn, S.E., Arthington, A.H., Fawcett, J.H., McKenzie-Smith, F.J. and Wright, $A$.

Australian Rivers Institute and eWater Cooperative Research Centre, Griffith

University, Nathan, Queensland, 4111, Australia.

* Corresponding author. Email: s.balcombe@griffith.edu.au

\section{SUMMARY}

1. Floodplain inundation provides many benefits to fish assemblages of floodplain river systems, particularly those with a predictable annual flood pulse that drives yearly peaks in fish production. In arid-zone rivers, hydrological patterns are highly variable and the influence of irregular floods on fish production and floodplain energy subsidies may be less clear-cut. To investigate the importance of floodplain inundation to a dryland river fish assemblage, we sampled fish life stages on the

20 floodplain of Cooper Creek, an Australian arid zone river. Sampling was focused around Windorah during a major flood in January 2004 and in isolated waterholes in March 2004 following flood drawdown.

2. Of the 12 native species known to occur in this region, 11 were present on the floodplain, and all were represented by at least two of three life-stages - larvae, juveniles or adult fish. Late stage larvae of six fish species were found on the floodplain. There were site-specific differences in larval species assemblages, individual species abundances and larval distribution patterns among floodplain sites. 3. Significant growth was evident on the floodplain, particularly by larval and juvenile fish, reflecting the combination of high water temperatures and shallow, food rich

30 habitats provided by the relatively flat floodplain.

4. Low variation in biomass, species richness and presence/absence of juvenile and adult fish across four floodplain sites indicates consistently high fish productivity across an extensive area.

5. Similarities and differences in fish biomass between the floodplain and isolated post-flood waterholes suggest high rates of biomass transfer (involving the most abundant species) into local waterholes and, potentially, biomass transfer by some species to other waterholes in the catchment during floodplain inundation and after floods recede.

6. The high concentration of fish on this shallow floodplain suggests it could be a key area of high fish production that drives a significant proportion of waterhole productivity in the vicinity. The Windorah floodplain provides favourable conditions 
necessary for the spawning of some species and juvenile recruitment of the majority of species. It is also appears to be a significant conduit for the movements of fish that underpin high genetic similarity, hence population mixing, of many species throughout the Cooper Creek catchment. The high floodplain fish production in turn provides a significant energy subsidy to waterholes after floodwaters recede.

7. The identification of key sites of high fish production, such as the Windorah floodplain, may be important from a conservation perspective. Key management principles should be: maintenance of the natural flooding regime; identification of the most productive floodplain areas; and maintenance of their connectivity to anastomosing river channels and the remnant aquatic habitats that ultimately sustain this fish assemblage through long-term dry/drought and flood cycles.

Running Head: Fish and floods in an arid zone river

Keywords: floods, fish biomass, fish movement, floodplains, arid zones

\section{Introduction}

60

The majority of Australian rivers flow through arid or semi-arid regions (Thoms \& Sheldon, 2000) and are characterised by highly variable and unpredictable flow regimes (Walker, Sheldon \& Puckridge, 1995; Puckridge et al., 1998). Typically the fish assemblages of dryland rivers exhibit high temporal variability in assemblage structure, often showing dramatic 'boom and bust' patterns of productivity corresponding to periods of flood and drought (Gehrke et al., 1995; Walker, Puckridge \& Blanch, 1997; Arthington et al. 2005). During dry periods, fish are restricted to isolated waterholes and their energy requirements are largely fuelled by autochthonous primary production (Bunn, Davies \& Winning, 2003). During floods,

70 many previously isolated waterholes become connected and fish have opportunities to disperse over large areas of floodplain and utilize a range of newly inundated habitats and food resources (Balcombe et al. 2005).

The flood pulse concept (FPC, Junk et al. 1989) encapsulates the key importance of flooding to rivers through the interaction between a river and its

75 floodplain. The FPC views rivers and floodplains as being dynamically linked, forming part of a single, but variably (spatially and temporally) connected system with strong hydrological and ecological process links between the two components. As a result of lateral floodplain-river interactions much of the riverine biomass in floodplain rivers is derived from the floodplain (Lewis et al. 2001). In tropical and 80 sub-tropical river systems the benefits afforded to fish assemblages by extensive annual floodplain inundation cannot be understated as it is the predictable annual flood pulse that drives massive fish production in some of the world's most productive freshwater fisheries (Sparks; 1995; Bayley, 1998; van Zalinge et al., 2000; Craig et al., 2004). Such systems support fish species adapted to utilise the vastly increased habitat and food resources made available by the predictable annual floodpulse. In dryland rivers, however, flood-pulses are highly variable and unpredictable in frequency of occurrence as well as extent and duration of floodplain inundation (Walker, Puckridge \& Blanch, 1997; Puckridge et al., 1998). This raises the question of whether fish in arid-zone rivers are adapted to take advantage of irregular flooding, 
90 and whether such floods drive fish production and floodplain energy subsidies to the extent observed in tropical and sub-tropical river systems (Craig et al., 2004).

Cooper Creek in southwest Queensland, Australia, is a dryland floodplain river with one of the most variable and unpredictable hydrological regimes in the world (Puckridge et al., 1998). Previous studies have shown that flooding plays an important role in structuring the fish assemblages that remain in isolated waterholes after floods recede, such that during dry periods the abundance of some species is largely a function of the area of floodplain inundated during the antecedent flood (Arthington et al. 2005; Bunn et al., 2006a). When in flood the Cooper Creek floodplain provides a massive 'boom' of floodplain food resources that fish can

100 exploit to support growth and biomass production (Balcombe et al. 2005). There is some knowledge of the influence of flooding on the structure and trophic ecology of fish assemblages in dryland rivers during dry periods (Arthington et al., 2005; Balcombe et al., 2006). However, we have a limited understanding of fish biomass relationships and the transfer of energy between floodplains and waterholes in these river systems. Furthermore there is limited basic ecological information on the species of fish, and their size-range and life-stages, that use the floodplains of Australian dryland rivers.

This paper has three aims: (1) to examine the diversity and size structure of fish assemblages on the Cooper Creek floodplain, (2) to determine whether fish

110 species presence/absence and biomass vary among floodplain localities (i.e. are fish distributed randomly across the floodplain?), and (3) to examine the relationship between fish biomass on the floodplain and in local waterholes during the post-flood period when they become disconnected from the floodplain and often from each other.

\section{Methods}

Study area

Cooper Creek is an Australian dryland river formed from the confluence of the Thomson and Barcoo Rivers in Western Queensland, terminating at Lake Eyre in the arid interior (Fig. 1). It is hydrologically one of the world's most variable rivers and

120 is virtually unregulated (Puckridge et al., 1998, Knighton \& Nanson, 2001). Like many Australian dryland rivers, Cooper Creek consists of a series of anastomosing channels and waterholes that become joined during unpredictable flood events. The river system, however, generally exists as a series of disconnected turbid waterholes (Bunn et al., 2003). The Cooper Creek catchment area covers approximately

$125300,000 \mathrm{~km}^{2}$ (Kotwicki 1987).

The climate of the Cooper Creek catchment is semi-arid with an average rainfall of less than $400 \mathrm{~mm}$ per year (Anonymous, 1998). Based upon 50 years of records (1939-1988), the average discharge at Windorah is 3.3 ML year ${ }^{-1}$. However, with inter-annual rainfall being highly unpredictable, there have been extended

130 periods of no flow and several high discharge flood events in recent times. For example, a spell analysis of the 50 years of Cooper Creek flow records revealed 154 no flow spells, 84 floods (> 20,000 MLday $^{-1}$ ) and 197 flow pulses (2-20,000 MLday ${ }^{-1}$ ) (Bunn et al., 2006b). The largest recorded flood event occurred in 1974 with more than 23 million ML discharged (Anonymous, 1998). Approximately 35\% of the 135 catchment consists of floodplain (Graetz, 1980; Gibling, Nanson \& Maroulis, 1998) and large floods can cover vast areas and take many weeks to travel down the extensive networks of channels and wetlands. 


\section{Sampling design}

On the floodplain, fish were sampled from four locations surrounding Windorah in January 2004 (Fig. 1). Fish were also sampled in four isolated waterholes in the vicinity of Windorah in March 2004. Apart from two small floods (March 1994 and February/March 1997) there was little flow in Cooper Creek between February 2000 and the previous last major floods in April 1990 and February 1991 (Bunn et al., 2003). There were two major floods between 2000 and 2004 (February 2000 and January 2004) and flow pulses in the summer/autumn of 2001, 2002 and 2003 (Bureau of Meteorology).

Three replicate tows of a beach seine ( $20 \times 2 \mathrm{~m}$ with $12 \mathrm{~mm}$ mesh) and three fyke nets were deployed at four locations on the floodplain (F1, F2, F3, F4) in January 2004 and in four waterholes, Murken (MU), Mayfield (MF), Glenmurken (GM) and Shed (SW) for the measurement of fish biomass. These waterholes are isolated waterbodies within the major channels, representing semi-permanent refugia in the system. The four waterholes represent the typical size range of waterholes in the system (bankfull ranges: Length $0.7-4.3 \mathrm{~km}$, Area 23000- $254000 \mathrm{~m}^{2}$; maximum depth $4.5-6.7$ and average depth 2.3-5.1m). The fish assemblages of the four waterholes have been previously studied with these methods (Arthington et al., 2005). A drag net (2.5 X 1.1 wide, $2.2 \mathrm{~m}$ deep, $1 \mathrm{~mm}$ mesh), a $250 \mu \mathrm{m}$ d-net and a $250 \mu \mathrm{m}$ plankton tow-net were also used to ensure no small-bodied species were missed in species richness counts. Ten larval light traps, as used by Humphries, Serafini \&

160 King (2002), were also set at each floodplain site and at an additional floodplain site (F5, see Fig. 1), to indicate variations in larval abundance across and within sites. This larval sampling program was also undertaken to assess the potential use of the floodplain for spawning, given that quantitative information on spawning and the occurrence of early life stages on the floodplains of Australian rivers is sparse. It

165 must be noted that the floodplain and waterhole sampling was undertaken about 2 months apart. It was not possible to sample waterholes during flood as they were totally inaccessible and totally submersed. The waterholes were sampled as soon as access was available and when they had become distinctly isolated (from each other) waterholes.

170 Fyke net wing width and sampling duration were recorded for each net for the subsequent calculations of catch per unit effort (CPUE), where CPUE represents the sum total of individual fish weights collected from three fyke nets set for $19 \mathrm{~h}$ with the wing entrance $10 \mathrm{~m}$ in width (see Arthington et al 2005).

For the estimation of biomass, fish captured in the beach seines on the

175 floodplain were killed with an overdose of benzocaine, then immediately placed into plastic bags and stored in a car-freezer. In the laboratory, fish standard lengths and weights (to the nearest gram) were measured and the summed weights for each species in each net were calculated to yield measures of biomass of individual species and in total.

180 Fish collected in the fyke nets and those from the waterhole beach seine collections were placed into a $25 \mathrm{~L}$ holding tub, before measuring their standard length and weight to the nearest gram; all were subsequently released at point of capture, with each net fully processed before starting on the next one.

One-way ANOVA was used to compare fish biomass measured from seine

185 hauls on the floodplain and in isolated waterholes. Following initial data screening, total biomass for each individual seine haul was $\log _{10}$ transformed to meet the assumptions of ANOVA. We then used Tukeys HSD post-hoc tests to account for 
biomass differences among each possible pair of sampling sites. All univariate analyses were performed using SPSS $\odot 11.5$ (SPSSS inc, 1989-2002).

We compared patterns of fish presence/absence and biomass estimated from the 2004 floodplain fyke samples and the 2004 waterhole samples using non-metric multidimensional scaling (MDS). These plots were generated from a Bray-Curtis similarity matrix generated from logarithmic transformed fyke biomass measures, and from presence/absence transformations of species richness estimates based on all sampling methods, using Primer-E version 5 for Windows (Clarke \& Warwick, 2001). One-way analysis of similarity (ANOSIM) was used to test whether fish assemblages were differentiated among floodplain sites and the four waterholes in terms of species presence/absence and species' biomass using the same Bray-Curtis similarity matrices.

To enable the calculation of fish biomass transfer from the floodplain into waterholes it was necessary to subtract the potential biomass growth component between the two sampling periods ( $\sim 2$ mo between floodplain and waterhole sampling). These growth estimates were based upon size-frequency histograms (standard length in $\mathrm{mm}$ ) for the most abundant species (by biomass) captured during

205 the study on both the floodplain and in the waterholes. These histograms were constructed using incremental lengths of $25 \mathrm{~mm}$. It was not possible to use smaller increments due to the low numbers of fish captured, particularly on the floodplain. A number of assumptions were made when estimating growth rates. First, 0+ fish of any species found in the waterholes were assumed to have gained almost all of their

210 biomass from growth on the floodplain; in other words, it was assumed that they would either have been spawned on the rising flood or just prior to floodplain sampling and their biomass would have been negligible on the floodplain. Second, 0+ individuals were considered as fish $<100 \mathrm{~mm}$ S.L. for all species. To estimate the growth component of larger fish (1+) we attempted to follow size frequency shifts

215 between the floodplain and waterhole, but this was only successful for Macquaria sp. and $N$. erebi due to the low numbers of the other species on the floodplain. In general across all species, however, 1+ fish grew two size classes between floodplain and waterhole sampling occasions (two months apart) and this assumption was used to estimate the growth component for the 1+ fish of the other four species. Mean

220 biomass estimates were calculated for each fish size class based upon length-weight relationships for each of the species. These were developed from a database of measurements on fish collected from Cooper Creek waterholes between 2001 and 2004. Growth gain $(G)$ of any given fish size class was estimated: $G_{w s c}=T_{w s c}\left(M_{w s c}\right.$ $-\mathrm{MB}_{\mathrm{fsc}}$, where $\mathrm{TI}_{\mathrm{wsc}}=$ total individuals for given size class in waterholes, $\mathrm{MB}=$ mean

225 fish biomass for given size class, $w s c=$ waterhole size class, $f s c=$ floodplain size class. The total growth gain for any species is the sum of all $\mathrm{G}_{\mathrm{wss}}$ for that species.

To develop the likely fish biomass budget, we estimated the relative floodplain area with characteristics similar to the features of our sampling sites. These features were: relatively flat floodplain, shallow during the flood ( $<1.5 \mathrm{~m}$ deep) and

230 delineated by potentially deeper, more dissected (by channels) zones identified using both satellite imagery and topographic maps. This type of floodplain area is depicted in Figure 1 by the lightly shaded enlargement showing the locations of individual sampling sites. The approximate area of this type of floodplain in the vicinity of Windorah was about $15 \mathrm{~km}^{2}$ based upon topographic and satellite imagery, while the 235 total area of local waterholes was calculated to be about $1.1 \mathrm{~km}^{2}$. Hence, we estimated biomass budgets by comparing the ratio of our measured floodplain biomass multiplied by 14 (the differential between floodplain and waterhole area) to 
the waterhole biomass less the growth component. This final calculated ratio would be expected to be approximately $1: 1$ if fish floodplain biomass is returned only into local waterholes.

\section{Results}

\section{Distribution}

245 The inundated Cooper Creek floodplain was clearly an important habitat for fish, with 11 native species found on the floodplain (Table 1). The range of fish lengths for each species indicated high variability in the size of most species of fish utilising the floodplain. At least two life-stages were found for all species except Ambassis sp. and B. welchii. Late stage larvae of six of the eleven native species (bony bream,

250 Nematalosa erebi; Lake Eyre golden perch, Macquaria sp.; Hyrtl's tandan, Neosilurus hyrtlii; silver tandan, $P$. argenteus; Australian smelt $R$. semoni and spangled perch, $L$. unicolor) were found on the floodplain. Adults of all species other than $R$. semoni were caught on the floodplain during at least one of the two floods.

\section{Biomass variation among floodplain sites}

Comparison of seine and fyke net data revealed that seines consistently caught fewer species (three) than fyke nets (nine) with an average of only two species per site collected by seines and five using fyke nets (Tables 2 and 3). The majority of the

260 biomass from seine samples was comprised of Nematalosa erebi. In contrast, there was a much more even contribution of species to the total biomass in the fyke samples, with $N$. erebi accounting for only $14 \%$ of the total fyke biomass. Previous experience with fykes across a broad range of spatial and temporal conditions has suggested that they give reliable estimates of fish assemblage structure (e.g.

265 Arthington et al 2005; Balcombe et al 2006). Using this knowledge to account for the relative inefficiency of seine sampling on the floodplain, we multiplied all seine floodplain biomass estimates by seven to give the total biomass expected if all fish species were captured as efficiently as $N$. erebi.

There was mostly low variability in fish biomass among the four floodplain

270 sites based on collections from both seine and fyke net methods (Tables 2 and 3). Seine biomass was similar at F1 (11.2 \pm 0.7 S.E.), F3 (14.4 \pm 8.3 S.E.) and WP (15.6 \pm 9.4 S.E.), but total biomass was much lower at $\mathrm{F} 2$ than at the other three sites due largely to the very low biomass of $N$. erebi (Table 2). Although F2 biomass was low $(4.3 \pm 0.1$ S.E. $)$, ANOVA revealed no significant site effect on fish biomass. Similar

275 to the pattern in the seine samples, fyke catches revealed comparable biomass among the F1, F3 and WP sites. In contrast to the seine data, F2 fyke biomass was exceptionally higher than in the other three sites. This disparity was driven by the high biomass of the yellowbelly, Macquaria sp., at F2, in marked contrast to its distribution/biomass across the other three sites.

280 A total of 86 individual larvae, all at a late developmental stage, were collected from eighteen of the 45 larval light traps set on the floodplain (Table 5). Site F2 was the only sampling site where no larvae were recorded. The most abundant and widespread species were $N$. erebi and Macquaria sp., while N. hyrtlii was locally abundant at site WP. L. unicolor was found at the same sites as 
found at all sites where larvae were present, but in low abundance, while only one $P$. argenteus individual was recorded from all samples. This occurrence was at the WP site where the other plotosid catfish (N. hyrtlii) was at its most abundant.

\section{Comparisons among floodplain sites and isolated waterholes}

While there was a large disparity between the species composition in the seines compared to that of the fykes on the floodplain, this was not so for waterhole sampling. In the waterholes, fyke and seine species compositions were very similar, and especially so for the species contributing the bulk of total biomass (Table 2 and 3 ). This suggests that seine nets give a reliable indication of fish assemblage composition and production (biomass levels) in the waterholes, but are a less reliable sampling method on the floodplain.

Ordination of fyke data revealed that waterhole and floodplain assemblages based upon biomass data were separated in space, with floodplain sites skewed toward the right of the MDS plot and waterholes skewed to the left (Fig. 2A). Further testing of the data revealed that fish assemblages in the waterholes were indeed significantly different to those on the floodplain (ANOSIM: Global $\mathrm{R}=0.635, \mathrm{p}<0.03$ ). There appeared to be some separation in ordination space between waterhole and floodplain

305 fish assemblages based on species presence absence data, with waterholes placed toward the top of the plot and floodplain sites toward the bottom (Fig. 2A). However, ANOSIM revealed these differences to be non-significant (ANOSIM: Global $\mathrm{R}=$ 0.235 , not significant). Hence, the disparity between patterns in floodplain and waterhole biomass was largely due to the higher biomass per unit area of individual

310 species in the waterholes relative to their biomass per unit area on the floodplain. Species richness was calculated by the sum of all species presences at each site using all sampling methods. While waterhole assemblages appeared more speciose rich $(9.5$ $\pm 1.2 \mathrm{~S} . \mathrm{E})$ than those on the floodplain $(7.3 \pm 1.3 \mathrm{~S}$.E $)$, ANOVA revealed there to be no significant difference between the two. This also emphasises that the greatest 315 difference between waterhole and floodplain fish assemblages was mostly differences in biomass of the species.

There was no statistical analysis comparing floodplain and waterhole biomass calculated from seine hauls due to the inefficiency of the seine net on the floodplain. However, the biomass in the waterholes was much greater than on the floodplain 320 based upon both seine and fyke raw data (Table 2 and 3).

There was some apparent variability in biomass among the four isolated waterholes, particularly due to the low biomass at SW and this was confirmed by a significant site effect on total biomass (ANOVA: $\mathrm{F}_{3,8}=31, \mathrm{p}<0.001$ ). Tukey's HSD post-hoc tests showed that SW biomass was significantly lower than biomass at the other three waterholes. No other among-site differences were apparent.

\section{Relationship between floodplain biomass, growth and waterhole biomass}

Figure 3 shows the size structure of the six most abundant species (by

330 biomass) on both the floodplain and in local waterholes. N. erebi was the only species that was easy to interpret, with a growth shift from the date of capture on the floodplain to the date of capture in waterholes, this shift being apparent from the large number of individuals caught. However, it was still possible to estimate approximate growth percentages for all species based upon waterhole fish size structure, indicating that a significant biomass component came from larval and juvenile fish. These 
estimates show particularly high growth rates for P. argenteus and N. erebi (Table 4). The other species growth rates were estimated to be between 17 and $37 \%$, and the average growth rate of the whole assemblage was $38 \%$.

When growth rates are taken into account there is an interesting result for potential biomass transfer between the floodplain and local waterholes. Some species clearly had inflated CF:WG ratios (e.g. N. erebi 6:1) and some had relatively low ratios (L. unicolor $0.2: 1$ ), with most ratios still within the same order of magnitude (1:1), suggesting that a large component of floodplain biomass around Windorah must be transferred into local waterholes (Table 5). The one anomaly in this pattern of low ratios is Macquaria sp. (59: 1), an order of magnitude greater than the average ratio for the whole assemblage (5:1, Table 5), suggesting a net transfer of fish from the floodplain to areas other than the local waterholes we sampled. Even so, the floodplain to waterhole biomass ratio for the whole fish assemblage $(5: 1)$ suggests that the bulk of the fish biomass produced on the floodplain is transferred directly into local waterholes.

If the same logic used to interpret the fyke net data is applied to the seine data, the mean seine biomass on the floodplain was $11.3 \mathrm{~kg} \mathrm{ha}^{-1}$ (Table 2). However, given the relative inefficiency of seine nets on the floodplain (as discussed above) this figure might conceivably be more like $80 \mathrm{~kg} \mathrm{ha}^{-1}$. Mean seine waterhole biomass was 355 approximately $3590 \mathrm{~kg} \mathrm{ha}^{-1}$ (Table 2). Accounting for a growth component on the floodplain of $38 \%$, and using the x14 floodplain multiplication factor (to account for the greater floodplain than waterhole area), would then suggest a floodplain to waterhole biomass ratio of $0.3: 1$, which is within the order of magnitude estimated from the fyke net data. This finding also suggests a high level of transfer of fish from the floodplain into local waterholes.

\section{Discussion}

The shallow floodplain waters near Windorah were sites of high fish biomass during the 2004 summer flood, when the average fish production based upon quantitative seine hauls ranged from 3 to $34 \mathrm{~kg} \mathrm{ha}^{-1}$. However, under the sampling conditions encountered, seine netting was highly inefficient, being biased towards capture of Nematalosa erebi, presumably because other species were able to escape with ease. Based upon comparisons with fyke catch data, where N. erebi accounted for one

370 seventh of the total fyke biomass, we suggest a conservative estimate of floodplain fish biomass would be at least seven times the amount we measured in seines. As such, our estimate of fish floodplain production could be in the range of 21 to $240 \mathrm{~kg}$ $\mathrm{ha}^{-1}$, a figure reasonably comparable to data for some of the world's key freshwater fisheries such as fisheries in Bangladesh $\left(50-400 \mathrm{~kg} \mathrm{ha}^{-1}\right.$; Craig et al., 2004), the 375 Mekong (138-175 kg ha ${ }^{-1}$; van Zalinge et al. 2000) and the Amazon (24 kg ha ${ }^{-1}$; Bayley, 1998). These fisheries are sustained by annual flood pulses, whereas the Cooper Creek system floods irregularly, raising the question of whether similar sized floods produce similar responses or the 2004 flood we studied was in some way exceptional. Seining on the Windorah floodplain during a flood of similar magnitude in February 2000 revealed similar results to those from the present study (14-150 kg $\mathrm{ha}^{-1}$, S. Balcombe, unpublished data). This similarity of response to floods four years apart, and the congruence of productivity estimates in major floodplain rivers, suggests that the fish fauna of Cooper Creek is adapted to take advantage of 
intermittent floods and the resources and growth opportunities associated with extensive floodplain inundation (Craig et al. 2004).

The only native species not found on the floodplain near Windorah, but known to be present in the study area albeit in low numbers (Arthington et al., 2005), was the Cooper Creek tandan, Neosiluroides cooperensis Allen \& Feinberg 1998. The only exotic species captured during the two floods was the mosquitofish (Gambusia holbrooki). There was generally low variation in species richness and total biomass across the floodplain areas we sampled, suggesting a uniform spread of fish across the floodplain around Windorah. This even distribution suggests that the inundated floodplain provides a major conduit for movement of most of the fish species that spend dry periods confined to isolated waterholes distributed throughout the

395 catchment, as inferred in other floodplain rivers (Rodriguez \& Lewis 1997). Low levels of genetic variability at the catchment scale reported for four Cooper Creek species (Nematalosa erebi, Retropinna semoni, Neosilurus hyrtlii, and Porochilus argenteus) suggest that there is high genetic and therefore biotic connectivity throughout this catchment (Hughes \& Hillyer, 2006; Huey, Hughes \& Baker, 2006).

400 Furthermore, these same four species were found on the floodplain in both 2000 and 2004 (S. Balcombe, unpublished data) implying movements from isolated waterholes onto the inundated floodplain whenever the opportunity arises.

There was evidence that a number of species had spawned either early on the rising limb of floods or shortly prior to flooding. The rising flood thereby provides 405 access to the floodplain for all life-stages of at least half of the native species found in Cooper Creek. Hence, the floodplain is not only important for movement of individuals and for feeding and associated fitness benefits (Arthington et al., 2005; Balcombe et al., 2005) but may also provide conditions and resources needed for spawning of some species, and certainly supports juvenile recruitment of most

410 species. These floodplain processes and fish behaviours would maximise the chance of any individual waterhole starting the dry season with a diverse, abundant and healthy fish assemblage immediately after flood recession and would ultimately enhance the survival of fish through prolonged periods of 'bust' (Walker, Puckridge \& Blanch, 1997).

415 Only six of the eleven native species found on the floodplain were collected as larvae. This could indicate that we failed to capture larvae of the other five species using the floodplain at later life history stages, either due to the lack of sufficient larval sampling sites, or that these species had not spawned on the 2004 flood. The same six species caught as larvae represent the six most abundant and widespread

420 species found in the mid-reaches of Cooper Creek (Arthington et al, 2005), hence, the likelihood of catching their larvae may have been high compared to the other five species. However, the size structure of $0+$ fish of all species in the waterholes in March 2004 indicated either none or very little spawning of the other five species had occurred on the floodplain.

425 The distribution and abundance of larvae on the floodplain suggests that they had selected particular habitats rather than being randomly distributed across the entire floodplain area surveyed. The major difference between the sites where larvae were encountered and the site where no larvae were found was the presence of structural habitat, namely submerged tree trunks and fallen timber (sites: F1 F3 and 430 F4; Fig. 1) and terrestrial ground vegetation such as forbs and grasses at site F5. In contrast, at site F2 where no larvae where caught, there was little such structural habitat available. Habitat structure would presumably be important for the survival of fish larvae on the floodplain as it would provide refuge from predators and turbulence 
(King 2004; Humphries et al., 2006). It must be noted that there was an unusually high biomass of Macquaria sp. at site F2. Hence the lack of structural refuge from this top predator could account, at least in part, for the lack of larvae at this site. Another interesting field observation was that the traps containing plotosid catfish larvae (N. hyrtlii and P. argenteus) at site WP were all set in shallow ( $<1 \mathrm{~m}$ deep) indentations that were distinctly thermally stratified. This suggests that larvae of this catfish may select thermal refugia, possibly to escape high daytime water temperatures (maximum of $39^{\circ} \mathrm{C}$ ).

A significant amount of post-flood waterhole fish biomass was provided by growth of most species on the floodplain, particularly $N$ erebi and $P$. argenteus, with more than $50 \%$ of waterhole biomass attributed to floodplain growth. The floodplain 445 is a highly resource rich environment for the fish species found in this river system (Balcombe et. al., 2005). In 2004, floodplain water temperatures were logged every minute and were generally high, being between 26 and $39^{\circ} \mathrm{C}$, and mostly above $30^{\circ} \mathrm{C}$ for the majority of any 24-hour period (S. Balcombe, unpublished data). It is possible that some of the highest temperatures may actually be deleterious to some fish species 450 if they exceed their tolerances, which would explain why catfish larvae were found in cooler patches of water. However, despite this possibility, the high biomass gain via larval and juvenile growth indicates that such fish thrived on the floodplain. The combination of highly abundant food resources and high water temperatures would have led to accelerated growth rates (Welcomme, 1979; Weatherley \&Gill, 1987), 455 particularly of larval and juvenile fish, compared to fish living in waterholes where high daytime air temperatures are buffered by water depth.

This study has revealed the importance of the floodplain in providing a significant energy subsidy into local and probably also more distant waterholes via fish biomass transfer. This reaffirms that, like tropical rivers (Junk et al., 1989,

460 Lewis et al., 2001), lateral transfers of energy from the floodplain to the river are important aspects of Cooper Creek riverine function. It must be noted, however, that in our estimation of fish biomass budgets we have assumed that fyke nets are equally efficient on the floodplain compared with their performance in waterholes. It is conceivable that there could be a significant fish concentration effect in waterholes, 465 given that the nets are set along the banks and fish are effectively funnelled into the openings. The floodplain is an immense open system by comparison and there would be a much greater likelihood that fyke catch efficiency would be reduced compared to waterholes. Given the likelihood of underestimation of floodplain biomass, the waterhole: floodplain ratio for all species would decrease, thereby increasing the 470 probability that the local floodplain area could be a source of fish biomass for many more waterholes than those situated close by. Given the positive floodplain: waterhole ratios already noted for Macquaria sp. and $N$ erebi, these species seem highly likely to make both local and larger scale movements. Furthermore, all of the species found in this study have been sampled both on flood fronts and road crossings 475 at various stages of flooding in Cooper Creek (S. Balcombe, unpublished data), demonstrating their propensity for mass migrations throughout the flood cycle.

In our calculations of floodplain to waterhole ratios we have considered only a very small part of the Cooper Creek floodplain surrounding Windorah (Fig. 1). Hence, we would certainly have underestimated local floodplain production as there is a 480 much greater expanse of floodplain than the $15 \mathrm{~km}^{2}$ habitat type we sampled, which remains unaccounted for in our biomass estimates. This would also surely provide a significant energy subsidy to the river network (Lewis et al., 2001; Balcombe et al., 2005). The physical setting of the whole Windorah floodplain would make it an ideal 
source of fish production for other parts of the catchment in that the floodplain breaks out just below the confluence of the Thomson and Barcoo Rivers (Fig. 1). After the "choke" at this confluence the floodplain fans out to around $70 \mathrm{~km}$ wide (Gibling, Nanson \& Maroulis 1998), making it a particularly likely location for migrating fish from upstream to accumulate. Wide floodplains have already been shown to play an important role in structuring this fish assemblage (Arthington et al., 2005) and those

490 in other floodplain rivers (Christensen 1993; Welcomme 2001; Barko, Herzog \& O'Connell 2006). The configuration of the floodplain "choke" and "fan" at Windorah could be considered analogous to the floodplain delta of the Great Lake Tonle Sap on the Mekong River (Jensen 2001). As with the Tonle Sap fishery, the floodplain at Windorah during summer flooding is shallow (1.5m deep or less) and characterised by 495 high temperatures, high net productivity (Bunn et al., 2006a) and areas of low turbulence (S. Balcombe, pers. obs.). The coupling of low turbulence with high temperature in shallow waters is a significant driver of floodplain productivity (Schramm \& Eggleton, 2006).

We suggest that the floodplain around Windorah is a significant location and conduit for fish feeding, breeding and growth and that, as water recedes off this floodplain, fish are then able to migrate throughout much of the network of anastomosing channels, which remain connected by channel flows for some weeks after floodplain waters recede. This would support the findings of Hughey, Hughes \& Baker (2006) and Hughes \& Hillyer (2006) that at least some of the Cooper Creek fish 505 species come from a "panmictic" population. This panmixia is a result of a high level of interbreeding and hence genetic mixing at the catchment scale, which implies high levels of biotic connectivity achieved by fish movement and mixing during floods.

Many floodplain rivers across the globe have lost floodplain and river channel connections, both of which are likely to be important for the movement of different

510 species and different life-stages of species (Jensen 2001; Welcomme 2001; Barko, Herzog \& O'Connell 2006). We suggest that our results for floodplain and waterhole biomass relationships and, hence, the likely energy subsidies from the floodplain to local and more distant waterholes, may be applicable to other dryland floodplain rivers with unpredictable hydrological regimes. Hence some of the concepts revealed

515 by our study may be relevant to their management. Several aspects are of utmost importance from a management perspective: maintenance of the natural flooding regime; identification of the most productive floodplain areas; and, maintenance of their connectivity to anastomosing river channels and the remnant aquatic habitats that ultimately sustain this fish assemblage through long-term dry/drought and flood 520 cycles.

\section{Acknowledgements}

The authors would like to thank the Dryland Refugia team who provided field

525 support, Sandy Kidd for providing access to waterholes and substantial field support during the 2000 and 2004 floods, and David Smith for access to his property. The authors also thank two anonymous referees for their helpful comments on an earlier draft. This paper is a product of the Dryland Refugia research project funded by the former Cooperative Research Centre for Freshwater Ecology. Our research was 530 conducted under Queensland Fisheries Permit PRM00157K and Griffith University Animal Experimentation Ethics Committee permit AES/03/02. Completion of this 
paper was made possible by funding support from the eWater Cooperative Research Centre (Project 1.F.102). 


\section{References}

paper. Department of Natural Resources, Queensland Australia. ISBN 07242 7278.

Arthington, A.H., Balcombe, S.R., Wilson, G.A., Thoms, M.C. \& Marshall, J. (2005). Spatial and temporal variation in fish assemblage structure in isolated waterholes during the 2001 dry season of an arid-zone river, Cooper Creek, Australia. Marine and Freshwater Research 56, 25-35.

Balcombe, S.R., Arthington, A.H., Foster, N.D, Thoms, M.C, Wilson G.G. \& Bunn, S.E. (2006) Fish assemblages of an Australian dryland river: abundance, assemblage structure and recruitment patterns in the Warrego River, MurrayDarling Basin. Marine and Freshwater Research 57, 619-633.

Balcombe, S.R., Bunn, S.E., McKenzie-Smith, F.J. \& Davies, P.E. (2005). Variability of fish diets between dry and flood periods in an arid zone floodplain river. Journal of Fish Biology 67, 1552-1567.

Barko, V.A., Herzog, D.P. \& O’Connell, M.T. (2006). Response of fishes to floodplain connectivity during and following a 500-year flood event in the unimpounded Upper Mississippi River. Wetlands 26(1), 244-257.

Bayley, P.B.(1998). Fisheries and aquatic biodiversity management methods, current status and management options. Special Publication of the Canadian Journal of Fisheries and Aquatic Sciences 106, 385-398.

555 Bunn, S.E., Davies, P.M. \& Winning, M. (2003). Sources of organic carbon supporting the food web of an arid zone floodplain river. Freshwater Biology 49, 619-35.

Bunn, S.E., Balcombe, S.R., Davies, P.M., Fellows, C.S. \& McKenzie-Smith, F.J. (2006a) Aquatic productivity and food webs of desert river ecosystems. pp. 76-99. In: R.T. Kingsford (ed). Ecology of Desert Rivers. Cambridge University Press.

Bunn SE, Thoms MC, Hamilton SK, Capon SJ (2006b). Flow variability in dryland rivers: boom, bust and the bits in between. River Research and Applications 22, 179-186

565 Christensen, M.S. (1993) The artisanal fishery of the Mahakam River floodplain in East Kalamantan, Indonesia. III. Actual and estimated yields, their relationships to water levels and management options. Journal of Applied Ichthyology 9, 202-209.

Clarke, K.R., \& Warwick, R.M. (2001). Change in Marine Communities: An Approach to Statistical Analysis and Interpretation. 2nd Edition. (PRIMER-E Ltd: Plymouth, United Kingdom.)

Craig, J.F., Halls, A.S., Barr, J.J.F. \& Bean, C.W. (2004) The Bangladesh floodplain fisheries. Fisheries Research 66, 272-286.

Gehrke, P.C., Brown, P., Schiller, C.B., Moffatt, D.B., \& Bruce, A.M. (1995). River regulation and fish communities in the Murray-Darling River system, Australia. Regulated Rivers: Research and Management 10: 15-38.

Gibling, M.R., Nanson, G.C. \& Maroulis, J.C. (1998) Anastomosing river sedimentation in the channel country of central Australia. Sedimentology 45, 595-619.

580 Graetz, R.D. (1980) The Potential Applications of LANDSAT Imagery to Land Resource Management in the Channel Country. CSIRO Divison of Land 
Resources Management, Perth, Western Australia. Technical Memorandum $80 / 2$.

Hughes, J.M. \& Hillyer, M.J. (2006) Mitochondrial DNA and allozymes reveal high dispersal abilities and historical movement across drainage boundaries in two species of freshwater fishes from inland rivers in Queensland, Australia. Journal of Fish Biology 68, 270-291. Suppl. B JUN 2006

Huey, J.A., Hughes, J.M. \& Baker, A.M. (2006) Patterns of gene flow in two species of eel-tailed catfish, Neosilurus hyrtlii and Porochilus argenteus (Siluriformes: Plotosidae), in western Queensland's dryland rivers. Biological Journal of the Linnean Society 87, 457-467.

Humphries, P., Serafini, L.G. \& King, A.J. (2002) River regulation and fish larvae: variation through space and time. Freshwater Biology 47, 1307-1331.

Jensen, J.G. (2001) Managing fish, floodplains and food security in the Lower Mekong Basin. Water Science and Technology 43(9), 157-164.

Junk, W. J., Bayley, P. B., and Sparks, R. E. (1989). The Flood Pulse Concept in river-floodplain Systems. Proceedings of the International Large Rivers Symposium (LARS) (Ed. D. P. Dodge.). Canadian Journal of Fisheries and Aquatic Sciences Special Publication 106, 110-27.

600 King, A.J. Ontogenetic patterns of habitat use by fishes within the main channel of an Australian floodplain river. Journal of Fish Biology 65, 1582-1603.

Knighton, A.D. \& Nanson, G.C. (2001) An event based approach to the hydrology of arid zone rivers in the Channel Country of Australia. Journal of Hydrology 254, 102-123.

605 Kotwicki, V (1987) On the future of rainfall-runoff modelling in arid areas - Lake Eyre case study In Water for the future. Hydrology in perspective. Proceedings of the Rome Symposium Vol. 164 (eds J.C. Rodda and N.C. Matalas), pp.341351. IAHS Publication, Rome.

Lewis, W.M., Jr., Hamilton, S.K., Rodríguez, M., Saunders, J.F., III. \& Lasi, M.A.

610 (2001) Foodweb analysis of the Orinoco floodplain based on production estimates and stable isotope data. Journal of the North American Benthological Society 20, 241-254.

Marshall, J.C., Sheldon, F., Thoms, M.C. \& Choy, S. (2006). The macroinvertebrate fauna of an Australian dryland river: spatial and temporal patterns and environmental relationships. Marine and Freshwater Research 57, 61-74.

McGregor, G.B., Marshall, J.C. \& Thoms, M.C. (2006) Spatial and temporal variation in algal-assemblage structure in isolated dryland river waterholes, Cooper Creek and Warrego River, Australia. Marine and Freshwater Research 57, 453-466.

620 Puckridge, J.T., Sheldon, F., Walker, K. F. \& Boulton, A. J. (1998). Flow variability and the ecology of large rivers. Marine and Freshwater Research 49, 55-72.

Pusey BJ, Kennard MJ, Arthington AH. (2004) Freshwater Fishes of North-eastern Australia. CSIRO Publishing: Collingwood, Australia.

Rodriguez, M. A. \& Lewis, W. M. Jr. (1997). Structure of fish assemblages along environmental gradients in floodplain lakes of the Orinoco River. Ecological Monographs 67, 109-28.

Schramm, H.L. Jr. \& Eggleton, M.A. (2006) Applicability of the flood-pulse concept in a temperate floodplain river ecosystem: thermal and temporal components. River Research and Applications 22, 543-553.

630 Sparks, R.E. (1995) Need for ecosystem management of large rivers and their floopdplains. BioScience 45, 168-182. 
Thoms, M. C. \& Sheldon, F. (2000) Lowland rivers: an Australian perspective. Regulated Rivers: Research and Management 16, 375-83.

Van Zalinge, N.P., Thuok, N., Tana, T.S. \& Loueng, D. (2000) Where there is water, there is fish? Cambodian fisheries in a Mekong regional perspective, pp. 109139. In Common Property in the Mekong: Issues of sustainability and subsistence. Eds: M. Ahmed \& P. Hirsch. ICLARM Studies and Reviews, 160p.

Walker, K.F., Puckridge, J.T. \& Blanch, S.J. (1997) Irrigation development on Cooper Creek, central Australia - prospects for a regulated economy in a boom-andbust ecology. Aquatic Conservation: Marine and freshwater Ecosystems 7, 6373.

Walker, K. F., Sheldon, F., \& Puckridge, J. T. (1995). An ecological perspective on dryland river ecosystems. Regulated Rivers: Research and Management 11, 85-104.

Weatherley, A.H. \& Gill, H.S. (1987). The Biology of Fish Growth. Academic Press: London.

Welcomme, R.L. (1979) Fisheries Ecology of Floodplain Rivers. Longman Press: London.

650 Welcomme, R. L. (2001). Inland Fisheries Ecology and Management. Fishing News Books, Blackwell Science Ltd: Oxford, United Kingdom. 


\section{Tables}

Table 1. Size ranges in mm standard length of adults and juveniles of fish species present on the Cooper Creek floodplain at Windorah in January 2004 and summary of 655 life stages found (A - adult; J - juvenile; L - larvae). Total numbers captured are shown in brackets.

\begin{tabular}{|c|c|c|c|}
\hline Family/species & Common name & Size range $(\mathrm{mm})$ & Life stages \\
\hline \multicolumn{4}{|l|}{ Native species } \\
\hline \multicolumn{4}{|l|}{ Ambassidae } \\
\hline Ambassis sp. & northwest ambassis & $42-65(4)$ & A \\
\hline \multicolumn{4}{|l|}{ Clupeidae } \\
\hline \multicolumn{4}{|l|}{ Gobiidae } \\
\hline $\begin{array}{l}\text { Hypseleotris spp. } \\
\text { Melanotaeniidae }\end{array}$ & \multicolumn{2}{|c|}{ Melanotaeniidae } & $\mathrm{J}$ A \\
\hline $\begin{array}{l}\text { Melanotaenia splendida tatei (Zietz, } \\
\text { 1896) }\end{array}$ & desert rainbowfish & $38-56(10)$ & $\mathrm{J}$ A \\
\hline \multicolumn{4}{|l|}{ Perchicthyidae } \\
\hline Macquaria sp. & $\begin{array}{l}\text { Lake Eyre golden } \\
\text { perch }\end{array}$ & $29-392(95)$ & L J A \\
\hline \multicolumn{4}{|l|}{ Plotosidae } \\
\hline Neosilurus hyrtlii Steindachner, 1867 & Hyrtl's tandan & $120-179(22)$ & L A \\
\hline $\begin{array}{l}\text { Porochilus argenteus (Zietz, 1896) } \\
\text { Retropinnidae }\end{array}$ & silver tandan & $99-169(8)$ & L J A \\
\hline \multicolumn{4}{|l|}{ Terapontidae } \\
\hline $\begin{array}{l}\text { Bidyanus welchi (McCulloch \& Waite, } \\
\text { 1917) }\end{array}$ & Welch's grunter & $200-260(4)$ & $\mathrm{J}$ A \\
\hline $\begin{array}{l}\text { Leiopotherapon unicolor (Günther, } \\
\text { 1859) }\end{array}$ & spangled perch & $34-140(53)$ & L J A \\
\hline $\begin{array}{l}\text { Scortum barcoo (McCulloch \& Waite, } \\
\text { 1917) }\end{array}$ & Barcoo grunter & $184-280(6)$ & $\mathrm{J}$ A \\
\hline \multicolumn{4}{|l|}{ Exotic species } \\
\hline \multicolumn{4}{|l|}{ Poeciliidae } \\
\hline Gambusia holbrooki (Girard, 1859) & mosquitofish & $9-43(8)$ & $\mathrm{J}$ A \\
\hline
\end{tabular}


Table 2. Mean fish production $\left(\mathrm{kg} \mathrm{ha}^{-2}\right)$ calculated from three seine hauls (each area seined $=31.8 \mathrm{~m}^{2}$ ) collected from four sites $(\mathrm{F} 1-\mathrm{F} 4)$ on the Cooper Creek floodplain at

660 Windorah in January 2004; and in four isolated waterholes (MU, MF, GM, SW) in the same local area in March 2004.

\begin{tabular}{lrrrrrrrr}
\hline Site & F1 & F2 & F3 & F4 & MU & MF & GM & SW \\
\hline Ambassis sp. & 0 & 0 & 0 & 0 & 0.4 & 0.8 & 0 & 0 \\
N. erebi & 4.3 & 3.4 & 14.2 & 15.6 & 474.4 & 302.2 & 607.1 & 7.6 \\
Hypseleotris spp. & 0 & 0 & 0 & 0 & 0 & 0 & 0 & 0 \\
M. splendida tatei & 0.5 & 0 & 0.5 & 0 & 2.9 & 7.6 & 1.0 & 0 \\
Macquaria sp. & 0 & 0 & 0 & 0 & 14.5 & 97.4 & 61.2 & 9.5 \\
N. cooperensis & 0 & 0 & 0 & 0 & 0 & 0.5 & 0 & 0 \\
P. argenteus & 0 & 0 & 0 & 0 & 291 & 184.9 & 335.1 & 12.5 \\
N. hyrtlii & 0 & 0 & 0 & 0 & 41.1 & 12.9 & 9.4 & 0 \\
G. holbrooki & 0 & 0 & 0 & 0 & 0 & 0 & 0 & 0 \\
R. semoni & 0 & 0 & 0 & 0 & 0 & 0 & 0 & 0 \\
B. welchii & 0 & 0 & 0 & 0 & 0 & 30.4 & 0 & 0 \\
L. unicolor & 6.3 & 0.8 & 0.5 & 0 & 258.9 & 76.9 & 64.8 & 4.2 \\
S. barcoo & 0 & 0 & 0 & 0 & 48.1 & 544.9 & 77.6 & 7.1 \\
Mean production & 11.1 & 3.8 & 14.7 & 15.6 & 1131.3 & 1258.5 & 1156.1 & 40.9 \\
Fish production & $3-25$ & $2-6$ & $4-31$ & $2-34$ & $624-1752$ & $1022-1391$ & $581-1850$ & $14-67$ \\
range & & & & & & & & \\
\hline
\end{tabular}

Table 3. Fish catch per unit effort (CPUE) for three standardised fyke nets (kg per19h 665 setting time using a $10 \mathrm{~m}^{2}$ wing width) set at four locations on the Cooper Creek floodplain (F1-F4) at Windorah in January 2004; and in four isolated waterholes MU, MF, GM, SW) in the same local area in March 2004.

\begin{tabular}{lllllllll}
\hline Site & F1 & F2 & F3 & F4 & MU & MF & GM & SW \\
\hline Ambassis sp. & 13 & 0 & 0 & 6 & 0 & 0 & 0 & 0 \\
N. erebi & 293 & 1298 & 884 & 399 & 3522 & 2770 & 1526 & 7101 \\
Hypseleotris spp. & 0 & 0 & 0 & 0 & 0 & 0 & 0 & 0 \\
M. splendida tatei & 11 & 2 & 0 & 0 & 0 & 0 & 0 & 0 \\
Macquaria sp. & 1465 & 9196 & 965 & 3738 & 3126 & 908 & 1026 & 793 \\
N. cooperensis & 0 & 0 & 0 & 0 & 2055 & 573 & 0 & 3 \\
P. argenteus & 163 & 0 & 0 & 0 & 17410 & 3605 & 1030 & 240 \\
N. hyrtlii & 148 & 0 & 0 & 0 & 3760 & 1040 & 301 & 281 \\
G. holbrooki & 0 & 0 & 0 & 0 & 0 & 0 & 0 & 0 \\
R. semoni & 0 & 0 & 0 & 0 & 0 & 0 & 0.2 & 0 \\
B. welchii & 0 & 553 & 0 & 0 & 0 & 2335 & 47 & 27 \\
L. unicolor & 290 & 71 & 2 & 2 & 7345 & 7345 & 22647 & 95 \\
S. barcoo & 185 & 528 & 374 & 0 & 2440 & 2569 & 563 & 0 \\
Total cpue & 2568 & 11648 & 2225 & 4145 & 39658 & 21016 & 27140 & 8540 \\
\hline
\end{tabular}


Table 4. Larval fish species abundance (total individuals) collected from nine traps set at each of five sites (45 traps in total) on the Cooper Creek floodplain at Windorah.

Numbers in parentheses indicate the trap number (from 1 to 9) of traps in which each species was present.

\begin{tabular}{lllllll}
\hline Site & F1 & F2 & F3 & F4 & F5 & Total \\
\hline N. erebi & $5(3,7)$ & 0 & $11(3,5,7,8)$ & $8(1,4)$ & $9(1,5,9)$ & $33(11)$ \\
Macquaria sp. & $5(3,7,9)$ & 0 & $6(5,7)$ & $7(1,3,4)$ & 0 & $16(8)$ \\
P. argenteus & 0 & 0 & 0 & $1(7)$ & 0 & $1(1)$ \\
N. hyrtlii & $1(3)$ & 0 & $3(2)$ & $15(4,7,8,9)$ & 0 & $19(6)$ \\
R. semoni & $2(3)$ & 0 & $1(2)$ & $2(1)$ & $3(5,9)$ & $8(5)$ \\
L. unicolor & $2(7,9)$ & 0 & $3(3,7)$ & $4(4,8)$ & 0 & $9(6)$ \\
Total abundance & 15 & 0 & 24 & 37 & 12 & 86 \\
Total traps with larvae & 4 & 0 & 5 & 6 & 3 & 18 \\
\hline
\end{tabular}

675 Table 5. Biomass components of six fish species used to estimate the transfer of energy between the Cooper Creek floodplain at Windorah in January 2004 and local waterholes in March 2004. W = fish biomass in post-flood waterholes, $\mathrm{P}=$ the percentage of $\mathrm{W}$ that can be attributed to fish growth between floodplain and waterhole sampling, $\mathrm{G}=$ the growth component as a biomass, $\mathrm{WG}=$ total waterhole biomass less the growth component, $\mathrm{AF}=$ floodplain

680 biomass x 14 (to correct for the differential between sampled floodplain area and local waterhole area), CF:WG is the ratio of floodplain to waterhole biomass corrected for area differences. *Biomass measurements are based on fyke CPUE.

\begin{tabular}{lllllll}
\hline & $\begin{array}{l}\text { *Waterhole } \\
\text { biomass } \\
(\mathrm{W})\end{array}$ & $\begin{array}{l}\% \\
\text { Growth } \\
(\mathrm{P})\end{array}$ & $\begin{array}{l}\text { Total } \\
\text { biomass } \\
\text { from } \\
\text { Growth } \\
(\mathrm{G})\end{array}$ & $\mathrm{W}-\mathrm{G}(\mathrm{WG})$ & $\begin{array}{l}\text { *Corrected } \\
\text { floodplain } \\
\text { biomass (CF) }\end{array}$ & $\begin{array}{l}\text { CF:WG } \\
\text { ratio }\end{array}$ \\
\hline N. erebi & 3730 & 56 & 2071 & 1659 & 10066 & $6: 1$ \\
Macquaria sp. & 1463 & 37 & 546 & 917 & 53744 & $59: 1$ \\
P. argenteus & 5571 & 69 & 3844 & 1727 & 574 & $0.3: 1$ \\
N. hyrtlii & 1346 & 25 & 337 & 1009 & 518 & $0.5: 1$ \\
L. unicolor & 9358 & 26 & 2433 & 6925 & 1274 & $0.2: 1$ \\
S. barcoo & 1393 & 17 & 237 & 1156 & 3808 & $3: 1$ \\
Total cpue & 25000 & $38 *$ & 9500 & 15500 & 71400 & $5: 1$ \\
\hline
\end{tabular}


Figure 1. Map of the Cooper Creek catchment and sampling sites in the region of Windorah, Western Queensland. Light shading indicates shallow, flat floodplain areas, representing the sampling area. Dark shading indicates variable topography, including shallow and

690 deep channels, resulting in deeper floodplain zones not represented by our sampling. Floodplain sites are designated F1, 2, 3 and 4. Waterhole sites are Murken waterhole (MU), Mayfield waterhole (MF), GlenMurken waterhole (GM) and Shed waterhole (SW)

Figure 2. Multidimensional scaling ordination plots of Axis $1 \mathrm{v}$ Axis 2 showing 695 floodplain and waterhole patterns for (a) fish species biomass and (b) fish species presence/absence.

Figure 3. Size-frequency distributions of six fish species on the floodplain (left panel) and in waterholes (right panel) at Cooper Creek, Windorah 


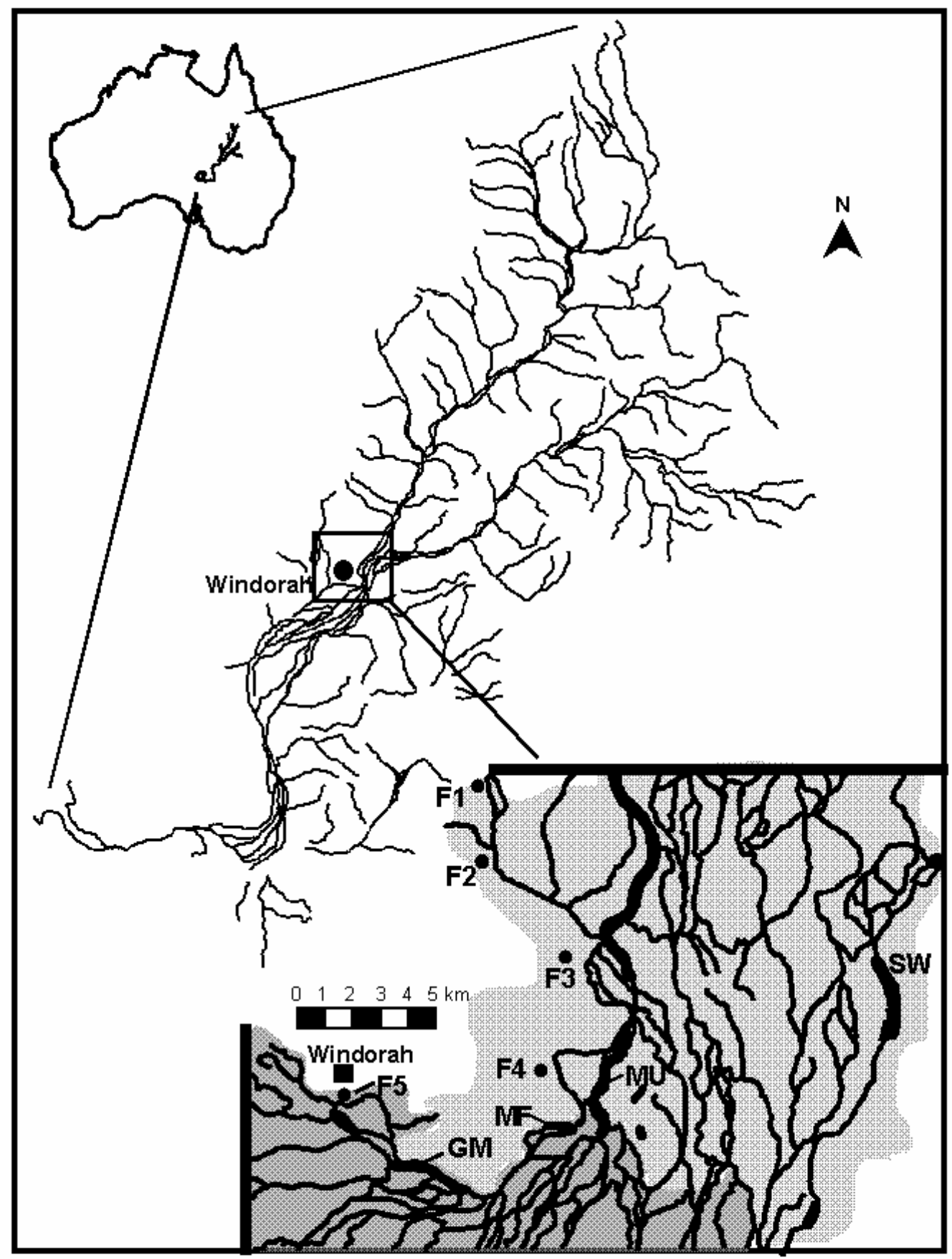

700 

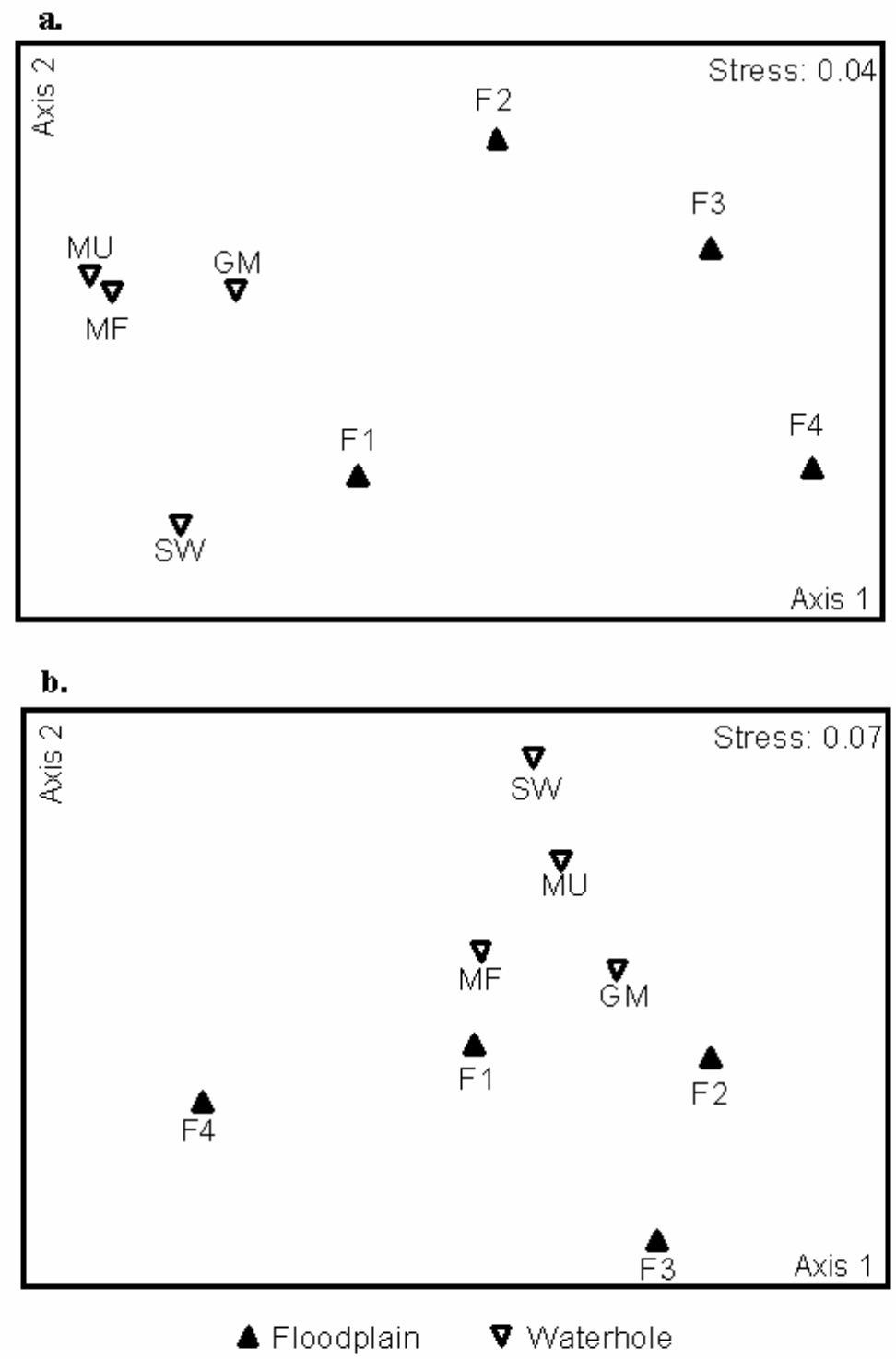


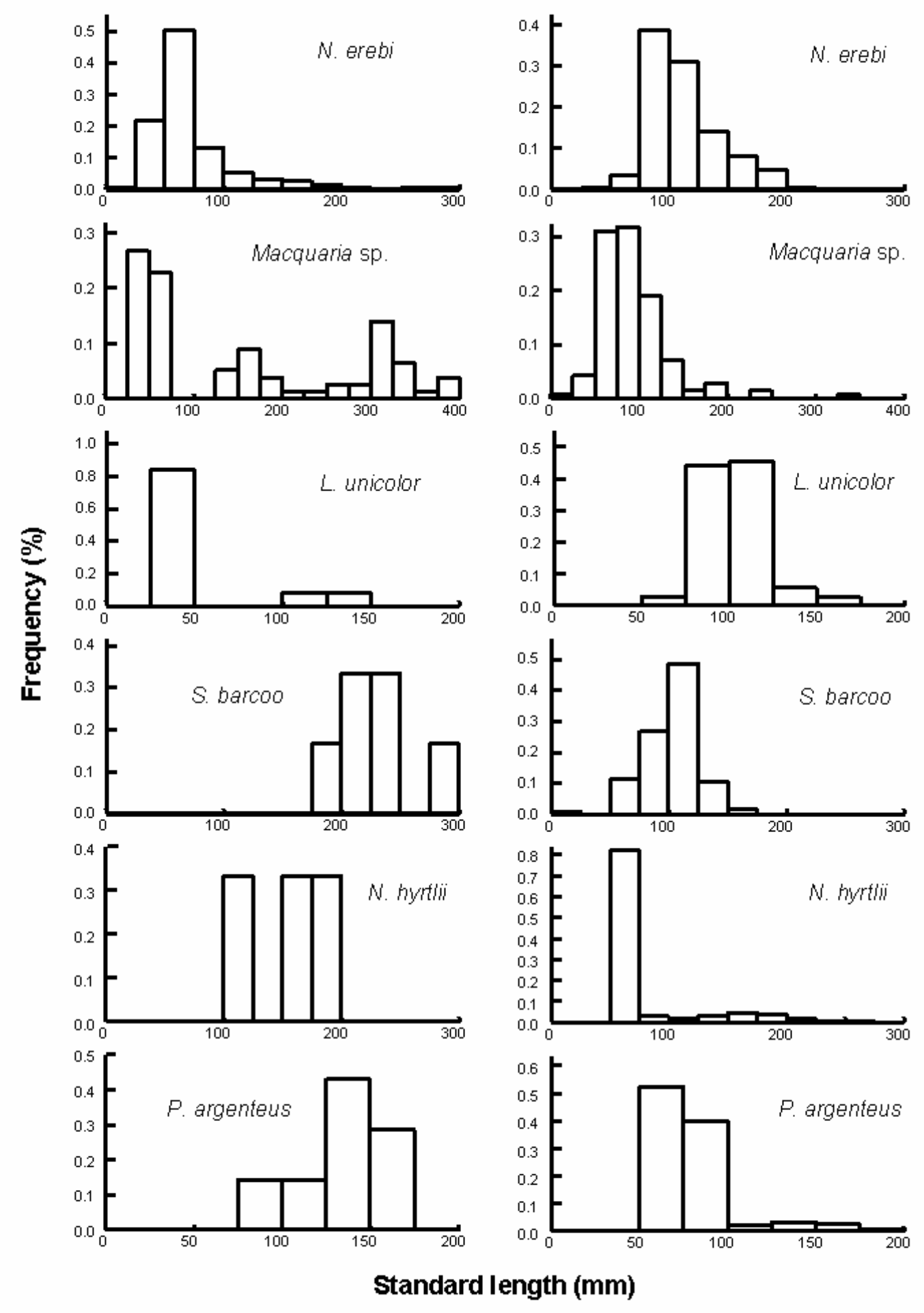

